\title{
AC 2007-2686: ENGINEERING MATERIALS IN A JUNIOR HIGH AND HIGH SCHOOL OUTREACH PROGRAM
}

\section{John Bridge, Maine Maritime Academy}

John W. Bridge, graduated from the U.S. Air Force Academy in Colorado and from the University of Dayton in Ohio with degrees in engineering mechanics and materials engineering. He served for over 20 years as an Air Force engineering officer and retired as a Lieutenant Colonel. He has taught mechanical engineering at several institutions including the U.S. Air Force Academy and the U.S. Military Academy at West Point, New York. He is a registered Professional Engineer and currently an Assistant Professor of Engineering at Maine Maritime Academy in Castine, Maine. He can be contacted at john.bridge@mma.edu

\section{Barbara Fleck, Maine Maritime Academy}

Barbara Fleck is an Associate Professor in the Engineering Department at Maine Maritime Academy and a professional engineer. She began teaching at MMA in 1994 after working with several research and development groups, including Battelle Columbus Laboratories, Brookhaven National Laboratory, Sunpower, Inc. and Stirling Technology, Inc. She can be contacted at Maine Maritime Academy, Castine, ME 04420; 207-326-2103, or bfleck@mma.edu 


\title{
Engineering Materials in a Junior High and High School Outreach Program
}

\begin{abstract}
Discovery Voyage (DV) is an outreach program that began at (our institution) in 1995. The goals of the program are to bring junior high and high school students to campus to learn about the programs and majors we offer. Because of our remote location and specialized programs, many students in the state are not aware of our engineering and technology majors. Invitations to teachers in schools throughout the state have resulted in over 7000 participants in the Discovery Voyage program since its inception.

A key component of the DV program is an engineering materials discussion and demonstration. Using materials including chalk, wood strips, plastic straws, and paper clips as examples, students discuss the general classes of materials and their properties. A new cable-stayed bridge under construction nearby is used as a prompt for students to generate a list of desirable properties for structural materials. Demonstrations including tensile tests, compression tests, and the effects of heat-treating steel are included in the program.

Although the main objective of the Discovery Voyage program is to increase applications and enrollment at (our institution), we also want to positively influence the career aspirations of students in the state. Students who participate in the engineering materials discussion and demonstration learn about classes of materials, mechanical properties of materials and their measurement, and they talk to engineers about their work. Teachers throughout the state have been enthusiastic about participation in the program, and enrollments at (our institution) have been steadily increasing.
\end{abstract}

